\title{
Objectification of Colour Judging ${ }_{535.65}^{\text {UDC }}$
}

\author{
Kazuko Yамамото \\ Nippon Paints Co., Ltd.
}

\begin{abstract}
As the accuracy of paint colour demanded becomes high, it becomes necessary to adopt, a numerical and objective method in place of the conventional sensuous and subjective methods of colour determination. In the present report several problems pertaining to colour mesurements were discussed, and the possibility of the application of colour difference meters was studied.

Although it is impossible to measure colour itself with a colour difference meter, it is possible to represent numerically the colour difference between two similar colours. It was found that the instrument has to be warmed up sufficiently before any measurements are made, and that the kinds of substrate and the conditions of film preparations have to be specified in order to obtain reproducible and results. In view of the practical aspects of paint application and of colour difference measurements, it appears that the reasonable value of colour diffence to standardize $\mathrm{E}-2$.
\end{abstract}

* Minami Shinagawa, Shinagawa-ku, Tokyo 


\title{
色判定方法の客観化について ${ }_{5335.65}^{\mathrm{UDC}}$
}

山本和子

\begin{abstract}
要
旨

色が広く一般に使用されるようになるにつれて，色の良否判定に対する使用者の要求は次第 にシビアなものになってきている。したがって塗料の色管理も従来の官能的, 主観的な方法か ら数值的，客観的な方法に移行することの必要性が痛感されるにいたっている。本報告では塗 料の色を判定するに当たって生じるいくつかの問題点について論じ，あわせて測定器使用の可 否について検討を行なった。すなわちハンター型色差計を塗料規格面に取り入れる場合の器差 による測定值のバラッキその他について測定を行ないつぎのような結論を得た。

1）ハンター型色差計は色の絶対測定を行なうのに使用することは不適当であるが，近似色 間の色差を数值化して表示する目的には使用できる。

2）ただしこの場合, 事前に十分計測器が定常状態にあることを確認する必要がある。

3）色を比較するのに用いる試験片を作成する際は，下地の材質，塗装条件などをはっきり 規定しておく必要がある。

4）塗料の実用性扔よび測定の妥当性からも判断して, 塗料規格内に取り入れる色差值とし ては $\Delta E=2$ 程度が適当と判断される。
\end{abstract}

\section{1. は じめに}

塗料の色は被塗物の美化に大きな影響を与えるので使 用者側の関心も高く, 塗料の色管理はメーカーにとって 重要な仕事の一つとなっている。しかしながら常に, 全 く同じ色を作り出すことは不可能であって, 求められた 色に対してできるだけバラッキの少ない(色差の小さい) ものが提供されるように管理をすることがメーカーとし て必要な技術となってくる。色管理をしていくための良 否の判定は, 従来から主として視感による官能検査によ って行なわれてきたが，この方法は個人差，環境差など による判断差を生じることが多く, しばしば問題を起こ していた。色管理をきびしく実施するためにはむず，誰 もがいつでも同一物に対して同じ判断を下せることが前 提となるが，視感による官能的色判定にはさきに述べた 上うな問題点があり，このため実用的でかつ客観的な判 定方法の確立の必要性が生じてきた。

色管理に関する問題は複雑多岐にわたっていて容易に 解決できる問題ではないが，本報告では判定を実施する 上での問題点と, 客観的判定方法の一手段としてのハン ター型色差計による色差判定について検討した結果を述 ベる。

昭 42. 8. 2 受理

*日本ペイント株式会社

東京都品川区南品川 4-1-15

\section{2. 色判定に影響を与える問題点}

過去の経験に基づいて色判定に影響を与兄ると考兄ら れる諸点をあげると，(1)試験片作成上の問題，(2)比較対 象上の問題，(3)判定上の問題，の三つに大別される。

\section{$2 \cdot 1$ 試験片作成上の問題}

同一塗料を用いても，次の条件差により色の差を生じ ることがある。

1）使用試験板の材質差……゙゙リキ, ガラス, 鉄, 紙 なぞ。

2）塗装方式差……ラ塗り,ドクターブレード塗り, 吹付ヶ塗りなど。

3）塗装時に和ける使用塗料の粘度差……希釈の仕方

4）試験片の塗膜厚の差

5）乾燥条件差……乾燥のスピード，乾燥時の温度招 よび湿度など。

\section{$2 \cdot 2$ 比較対象上の問題}

色の判定は必らず標準品と比較して行ならが，比較す る対象によってはつぎのような問題がある。

1）標準品と試料との塗料品質の差……顔料, ビヒク ルの種類や組成が異なる。

2）標準塗片々試験片（色判定用塗片）との作成条件 差……塗装力法, 乾燥方法, 作成時期などが異なる。

3）標準塗片と試験片との使用試験板の材質差

例紙とブリキでは素地の影響が異なる。 
4）標準塗片の経時変化……きず, よごれ, 光沢減少, 変色など。

5）光沢差……つぎのような光沢差があると色判定は 幻惑される。

a．塗料品質が異なる場合の標準塗片と試験片との 光沢差。 b · 経時した標準塗片と作成したての試験片 との光沢差。(同一塗料品質の場合)

\section{$2 \cdot 3$ 判定上の問題}

現在一般汇用いられている色判定方法は, 主として視 感による方法と計測器による方法とであるが，それぞれ つぎのような問題の岕ることが認められている。

\section{$2 \cdot 3 \cdot 1$ 視感判定}

視感判定は色の差を精細涀分けることができるとい う利点が岕るが，その色の差を数值的に表現することは むずかしく，また個人差，環境差を生じやすい。つぎに 視感覚の個人差について行なった実験の一例を示す。

「実験例」

1）目的 同一塗板の判定についての個人差の確認

2）実験条件

\section{a. 試料叙板}

No. $1 \quad 7.5 \mathrm{BG} 4 / 2$ 標準との色差 $(\Delta E) 1.2$ のもの

No. $2 \quad 7.5 \mathrm{BG} 4 / 2$ 標準との色差 $(\Delta E) 0.1$ のもの

No. $35 \mathrm{PG} 8 / 1$ 標準との色差 $(\Delta E) 0.4$ のもの 備考 ここでいう $\Delta E$ はハンターの色差式より求め たものである。 $\left(\Delta E=\sqrt{\Delta L^{2}+\Delta a^{2}+\Delta b^{2}}\right)$

b. 測定者 色彩弁別テスト合格者 20 名。c . 測 定場所 一定場所の直接光でない自然光の下で $d$. 測定回数 午前, 午後, 一日 2 回で 3 日間, 合計 120 回 $(2 \times 3 \times 20) \mathrm{e}$. 調查方法 アンケート方式により 標準との色変化傾向感扔よび羑の認識程度を調査

3）結果 上記の条件で実験した結果はつぎのと拉りで あった。

a) 標準に対する試料塗板の色変化傾向感は,色差 $(\Delta E)$ の大小にかかわらず，個人によりかなりの差がある。 （図-1 参照） b ）標準に対する試料塗板の差の認識 程度は個人による差はめるが, 平均的にみた場合色 差の大小の区別はなされている。(図-2 参照）c） 同一塗板であっても午前と午後では感覚差のあるこ とが推察できる。(图-3 参照) d ) 色変化傾向感は 図-1 で明らかなと招り色差 $\Delta E$ の大きいものは小 さいものに比べて判定が同傾向となりやすく視感判 定と $E \Delta$ 判定との間併行関係があることが推察で きる。

$2 \cdot 3 \cdot 2$ 計測器判定

計測器を使用すれば数值化ができるので, 客観的判定

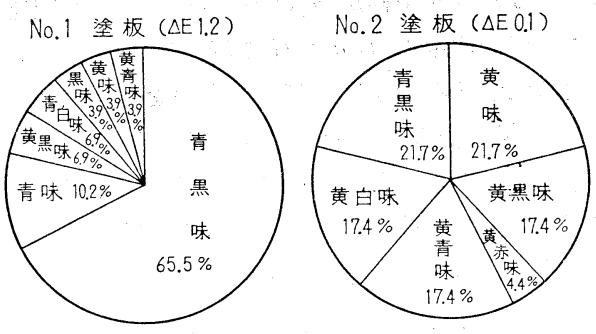

図-1 官能検査に上る色変化傾向感

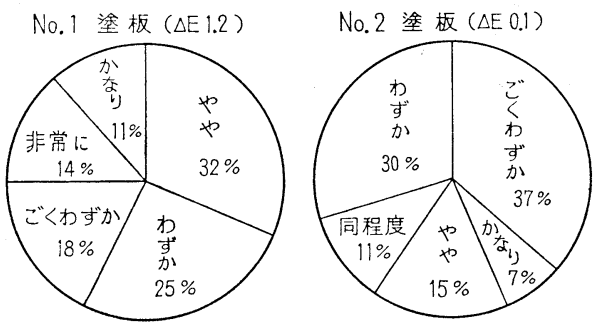

図-2 官能検查による色差の認識感

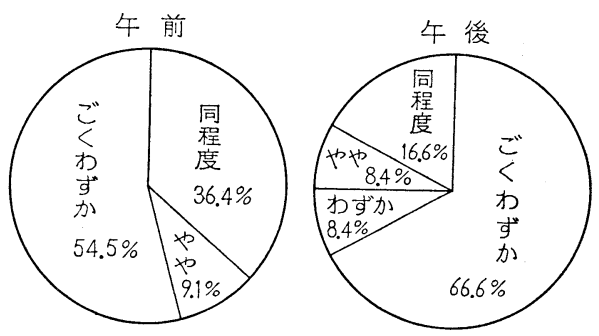

図-3 No. 3 泾板 $(\Delta E$ 0.4) の午前と午後の色 差の認識感

ができる利点があるが反面つぎのような問題点がある。

1）計測器の種類が異なれば, 同一塗板であっても, ちがった数值を示すことがある。

2）色空間は立体的であるため, 同じ数值の色差でめ っても方向が異なれば, 視感との間にずれを生じる ことがある。(同一色差式で算出したものでも)

しかしながら, 計測器の種類を統一してその機能が十 分発揮できるように管理をよくすれば，実用にかなった 数值による客観的色判定が可能と考兄られたので, 引き 続いてその検討を行なった。

\section{3. ハンター型色差計による色差判定}

色を数值管理するには， $L \cdot a \cdot b$ から求めた $\Delta E$ で表 示ができるハンター型色差計がもっとも簡便で実用的で あると現在は考觉られているよってここでは, ハンタ 一型色差計の器差と測定値のバラッキ幅について検討し た結果を報告する。すなわち，各所で使用しているハン ター型色差計の器差によるバラシキ幅の調查, おょび器 
差によるバラッキ幅が無視でさるかどうかも確認する目 的で, 同一塗板の $L \cdot a \cdot b$ 值の繰り返し測定および二つ の近似色色差の繰り返し測定の実験を行なった。

\section{$3 \cdot 1$ 同一塗板の $\boldsymbol{L} \cdot \boldsymbol{a} \cdot \boldsymbol{b}$ 值の繰り返し測定}

赤, 青, 黄の三色について同一不変色板の $L \cdot a \cdot b$ 值 を実験計画法（枝分れ実験）に基づいて 5 カ所で使用し ている 5 台の色差計を用いて繰り返し測定を実施した。

その結果は表-1 に示されていると拈りで，各色とも 測定器間执よび測定日間に差のあることがわかった。

なお色別, 測定器別の測定值の平均 $(\bar{x})$ とバラッキ範 囲（ 3 シグマ）は表-2, 表-3 のと和りであった。

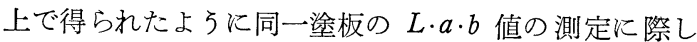
$\tau \nLeftarrow$

a 、測定器間および日間変動がある。

表-1 分散 分 析 結 果 $(n=190)$ 赤について

\begin{tabular}{|c|c|c|c|c|c|c|}
\hline 要 & 因 & $L$ & $a$ & $b$ & $F_{\phi_{2}}^{\phi_{1}}(0.01)$ & $F_{\phi_{2}}^{\phi_{1}}(0.05)$ \\
\hline \multicolumn{2}{|c|}{ 測定器間 } & \multicolumn{2}{|c|}{$5.42^{* *} \mid 22754.06 * *$} & $11.72^{* *}$ & 4. 43 & 2.87 \\
\hline 日 & 間 & $2014.22^{* *}$ & $6.75^{* *}$ & $23.41^{* *}$ & 2.70 & 2.10 \\
\hline 時 & 間 & 1.30 & 0.04 & 0.56 & 2.29 & 1.79 \\
\hline
\end{tabular}

青について

\begin{tabular}{|c|c|c|c|c|c|c|}
\hline 要 & 因 & $L$ & $a$ & $b$ & $F_{\phi_{2}}^{\phi_{1}}(0.01)$ & $F_{\phi_{2}}^{\phi_{1}}(0.05)$ \\
\hline \multicolumn{2}{|c|}{ 測定器間 } & $1284.37^{* *}$ & $9177.88^{* *}$ & $5666.82^{* * *}$ & 4.43 & 2.87 \\
\hline 日 & 間 & $2.91^{* *}$ & 0.45 & 1.53 & 2.70 & $2 \cdot 10$ \\
\hline 時 & 間 & 0.01 & 3.06 & 2.71 & 2.29 & 1.79 \\
\hline
\end{tabular}

黄について

\begin{tabular}{|c|c|c|c|c|c|c|}
\hline 要 & 因 & $L$ & $a$ & $b$ & $F_{\phi_{2}}^{\phi_{1}}(0.01)$ & $F_{\phi_{2}}^{\phi_{1}}(0.05)$ \\
\hline \multicolumn{2}{|c|}{ 測定器間 } & $1690.72^{* *}$ & $107.80^{* *}$ & $3146.17^{* *}$ & 4.43 & 2.87 \\
\hline 日 & 間 & 1.71 & 0.004 & 3. $40 * *$ & 2.70 & 2.10 \\
\hline 時 & 間 & 1.14 & 1.68 & 0.38 & 2.29 & 1.79 \\
\hline
\end{tabular}

備考 本実験の因子としては次のものを取り上げた。

1. 測定器 (対応のある変量) 2 . 日 (対応のない変量)

3. 時間 (対応のない变量) 4 . 測定者(対応のない変量)

表-2 測定器別 $L \cdot a \cdot b$ 測定值の $[\bar{x}]$

\begin{tabular}{c|c|c|c|c|r|r|r|r|r}
\hline \multirow{2}{*}{$\begin{array}{c}\text { データ } \\
\text { 色差計 }\end{array}$} & \multicolumn{3}{|c|}{ 赤 } & \multicolumn{3}{c|}{ 青 } & \multicolumn{3}{c}{ 黄 } \\
\cline { 2 - 9 } & $\bar{x}_{L}$ & $\bar{x}_{a}$ & $\bar{x}_{b}$ & $\bar{x}_{L}$ & $\bar{x}_{a}$ & $\bar{x}_{b}$ & $\bar{x}_{L}$ & $\bar{x}_{a}$ & $\bar{x}_{a}$ \\
\hline 1 & 33.2 & 56.8 & 18.9 & 49.7 & 2.1 & 19.5 & 86.7 & 13.0 & 38.2 \\
2 & 27.7 & 71.6 & 14.4 & 46.5 & 5.8 & -15.4 & 84.1 & -7.8 & 43.1 \\
3 & 34.8 & 54.1 & 17.7 & 49.1 & 1.0 & -20.4 & 86.3 & -11.3 & 40.1 \\
4 & 33.0 & 68.2 & 20.0 & 48.6 & -4.1 & -20.7 & 84.6 & -3.4 & 40.6 \\
5 & 28.0 & 72.9 & 14.1 & 47.3 & 8.0 & -17.8 & 84.1 & -9.5 & 43.1 \\
\hline
\end{tabular}

$(n=$ 各 30$)$ b . 各測定器の測定値や再現精度 (バラッキ幅) には 相当の差がある。

ことが判明した。したがってハンター型色差計は, 通常 いわれているよ5に二つの近似色間の色差の判定に用い るのが適当と考えられた。

\section{$3 \cdot 2$ 二つの近似色色差の繰り返し測定}

ハンター型色差計は二つの近似色色差測定に用いるの が適当と推察されたので，ここでは近似色の色差を測定 した時の色差計の器差や再現精度を調査するため, メー カーの異なる 3 台のハンター型色差計を用いて赤, 青, 黄 の三色について近似色色差を繰り返し測定した。その結 果は 表-4 に示されているよ5に 1) 繰り返し測定に よって求められた色差 $(\Delta E)$ の平均值 $(\bar{x})$ から判断す れば三色とも器差によるデータ差はほとんどない。

2）再現精度については測定器による差が あり，本実験でのバラッキ幅は $\mathrm{C}<\mathrm{A}<\mathrm{B}$ の順序であった。

測定器により，バラッキ幅に差を生じている のは，本実験では測定環境がそれぞれ異なっ ていたことと，色差計によっては，いくらか 定常性の保持に疑義があったことなどの原因 のためと想像され上記結果がそのまま測定器 構造上の問題に基づくものとはいらことはで きない。すなわちバラッキ幅のもっとも小さ い色差計 Cは理想的条件下（恒温室）での測 定であり，バラッキ幅のもっとも大きい色差 計 Bは図-4 に示されると抮り，A括よびC に比べて定常性が保持されていたかどうかに 疑いがある。したがって定常性の保持された 色差計を使用して，一般条件下で測定した場 合に期待できる再現精度は, 測定器の構造か ら考えて A 程度のバラッキ幅であろうと考え られる。

\section{4. 色差計による塗料の色管理}

以上に述べた検討の結果から，ハンター 型色差計は色の絶対值測定用としての使用 は困難であるが，近似色間の色差を数值化 して表示する目的には十分使用ができると 判断され，今回，国鉄より諮問を受けて設 置された日本車両工業協会の塗料研究会で も上記の趣旨の答申を国鉄に対して行なっ た。ただし塗料規格などの中にこの種の計 測器を取り入れる場合は注意を必要とする 幾つかの問題があり，上記研究会の報告書 
表-3 測定器別測定値 $L \cdot a \cdot b$ のバラッキ範囲（土 3 シグマ）

\begin{tabular}{|c|c|c|c|c|c|c|c|c|c|c|c|c|}
\hline \multirow{2}{*}{$\begin{array}{l}\text { データ } \\
\text { 色差計 } \\
\text { No. }\end{array}$} & \multicolumn{4}{|c|}{ 赤 } & \multicolumn{4}{|c|}{ 青 } & \multicolumn{4}{|c|}{ 黄 } \\
\hline & $\pm 3 \sigma_{L}$ & $\pm 3 \sigma_{o}$ & $a \pm 3 \sigma_{b}$ & $\pm \sqrt{\sigma_{L}^{2}+\sigma_{a}^{2}+\sigma_{b}^{2}}$ & $\pm 3 \sigma_{L}$ & $L\left| \pm 3 \sigma_{a}\right|$ & $a \pm 3 \sigma_{b}$ & $\pm \sqrt{\sigma_{L}^{2}+\sigma_{a}^{2}+\sigma_{b}^{2}}$ & $\pm 3 \sigma_{L}$ & $L \mid \pm 3 \sigma_{a}$ & $a \pm 3 \sigma_{b}$ & $\pm \sqrt{\sigma_{L}{ }^{2}+\sigma_{a}^{2}+\sigma_{b}^{2}}$ \\
\hline 1 & 0.40 & 0.63 & 0.40 & 0.85 & 0.29 & 0.73 & 0.29 & 0.84 & 0.24 & \begin{tabular}{l|l}
1 & 0.68
\end{tabular} & $3 \mid 0.48$ & 0.87 \\
\hline 2 & 0.36 & 0.85 & 0.21 & 0.94 & 0.49 & 0.21 & 0.25 & 0.62 & 0.25 & 50.20 & 0.21 & 0.38 \\
\hline 3 & 0.33 & 0.77 & 1.80 & 1.99 & 0.19 & 0.42 & 0.19 & 0.50 & 1.27 & 0.80 & 0.75 & 1.67 \\
\hline 4 & 0.63 & 2.64 & 0.54 & 2.77 & 0.47 & 0.50 & 0.45 & 0.82 & 0.60 & 0.78 & 0.57 & 1.26 \\
\hline 5 & 0.64 & 2.34 & 0.34 & 2.45 & 0.34 & $4 \mid 0.41$ & 0.47 & 0.71 & 0.19 & 0.42 & 0.07 & 0.47 \\
\hline
\end{tabular}
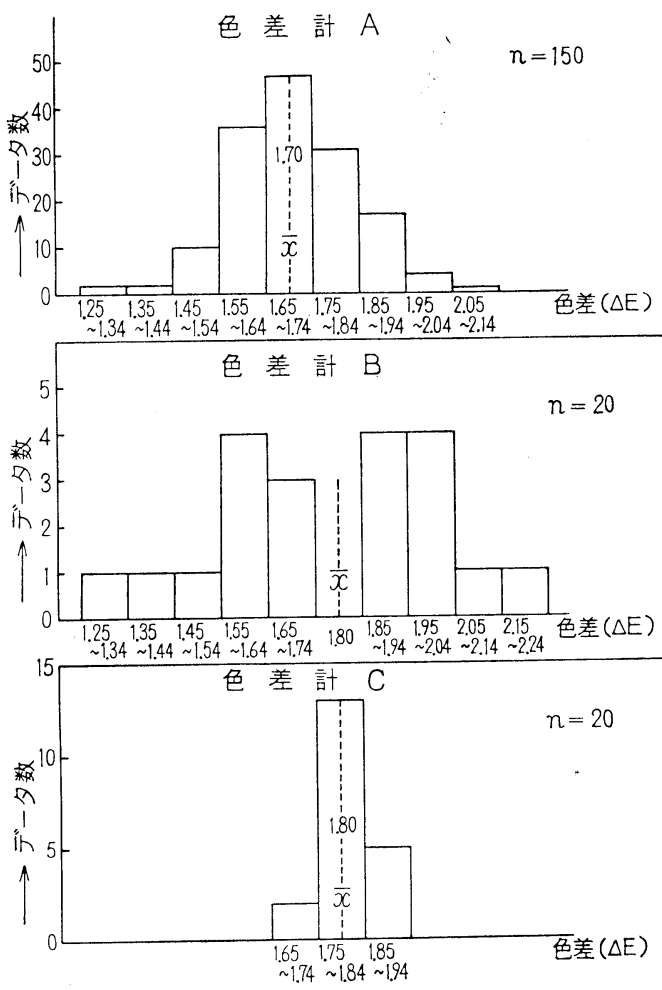

図-4 器種別色差 $(\Delta E)$ 測定值のヒストグラム の一例（赤について）

表-4 赤青黄三色の $\Delta E$ の $[\bar{x}]$ とバラッキ範团 $[s]$

\begin{tabular}{r|c|c|c|c|c|c}
\hline 色差計 & \multicolumn{2}{|c|}{$\mathrm{A}$} & \multicolumn{2}{c|}{$\mathrm{B}$} & \multicolumn{2}{c|}{$\mathrm{C}$} \\
\hline 測定值 & $\bar{x}$ & $s$ & $\bar{x}$ & $s$ & $\bar{x}$ & $s$ \\
\hline \multirow{2}{*}{ 赤 } & 1.73 & 0.13 & 1.78 & 0.24 & 1.81 & 0.06 \\
青 & 1.71 & 0.07 & 1.63 & 0.15 & 1.49 & 0.04 \\
黄 & 3.75 & 0.11 & 3.74 & 0.33 & 3.78 & 0.04 \\
\hline
\end{tabular}

備考 1. 測定法：試験片と標準との $\Delta E$ をランダムに 1 日 4 回以上の繰り返しを行ない 5 日間つづけた。

2. 測定場所 : 色差計 A, B 通常の実験室 色差計 C 恒温室 $\left.\left(20^{\circ} \mathrm{C}\right)\right\}$ で測定した。
の中では以下に述べるような諸点について適切な取り扱 いを実施に際して考慮するよう要望している。

\section{$4 \cdot 1$ ハンター型色差計の定常性の確認}

3.2 の器差検定の結果, 色差計で $\Delta E$ を測定するために は測定器が定常状態にあるかどうか，が問題となること が判明した。そこで測定に先立ち色差計の定常性を確認 するため, 次の 2 点についてチェックをする必要がある。

1）色標準板（不変色板で，できれば 3 原色を用いる とよい）の $L \cdot a \cdot b$ 表示值と実際の測定值との差が 2 以内にある。

2）二つの近似色色差の繰り返し（連続的） 5 回の測 定值の $\mathrm{R}$ (最大值と最小值の差) が 0.2 以内である。 上記チェックの結果異常がなければ定常状態にあるとし 試料板の測定を開始してよい。

備考 チェック項目は AS TMD-1365-55T などを参考 として決めた。

\section{$4 \cdot 2$ 色標準の設定}

色判定を色差 $(\Delta E)$ で行なうためには色標準が必要で あるが，この標準としては，1）カラーカードを使用す る。2）承認板（使用者からあらかじめ承認を受けた塗 料の塗り板）を使用する。の 2 方法が考兄られる。カラ 一カードを標準としたとさは視感で大体一致しているよ うにみ党ても

カラーカードと実際納入塗料との組成が異なる。

カラーカードと試験片との塗料条件が異なる。 などの理由で大きな規格值を設定することが必要とな る。実際納入塗料について一例を示すと, 図-5 のと拈 りで，特にハイディングの悪い有機顔料などを使用した ものは, 膜厚により試験板の材質の影響を受けて色差 $(\Delta E)$ が大きく変化する。

な绝によっては試験板材質や膜厚変化の影響を受け にくいものもあるのでその例を図-6に示す。

他方承認板を標準に用いた場合は，メーカーごとに標 準板が設定されるので，承認手続などの幾分のわずらわ しさはあるが標準板と納入塗料の組成や塗装条件を同じ 


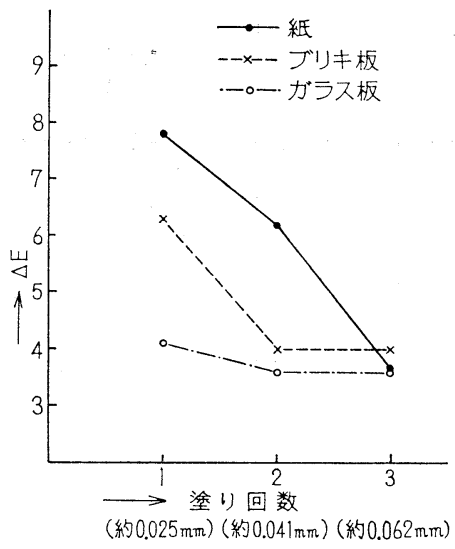

図-5 赤 2 号の試験板材質別・膜厚別の $\Delta E$ 変化（カラーカードに対して）

備考：ガラス板の $\Delta E$ が小さいのは，ガ ラス板に塗った色でカラーカード にあわせているためである

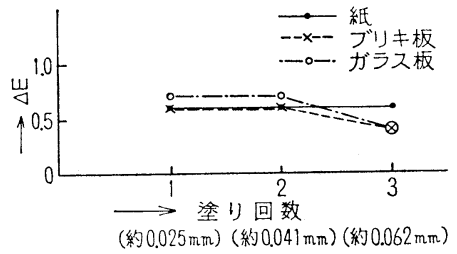

図-6 ブドー2 号の試験板 材質別 膜厚別 の $\Delta E$ 変化（カラーカードに対しての）

くすることが可能であり色差を小さく規制することがで きる。上記について比較検討した結果, 承認板を色標準と する方が実状にかなった適切な方法であると考学られ る。

\section{$4 \cdot 3$ 試験片作成条件の明確化}

同じ塗料を用いても試験片作成条件が異なると色差を 生じるのでつぎのように条件を規制する必要がある。

1）試験板の材質 承認板と同一とする。例 JIS-G3303 SPTEC-50 ブリキ板使用

2）希釈シンナー SA 448 フタル酸樹脂エナメル用 シンナー（吹付ヶ用）

3）吹付子時の塗料粘度 フォードカップNo. 4 で 25 \pm 1 秒 $\left(20^{\circ} \mathrm{C}\right)$

4) 膜厚 (乾燥)

隠ペい力の大きなもの $0.04 \sim 0.05 \mathrm{~mm}$ 隠ペい力の小さなもの $0.06 \sim 0.075 \mathrm{~mm}$

5）塗り回数 規定膜厚になるよう 2 回以上塗り重ね る。塗り重水のインターバルは

1 回目と 2 回目の間: 約 18 時間以上
2 回目之 3 回目の間 約 6 時間以上

6) 塗装方法 JIS-K-5400 3.5(2) 吹付塗りによる

7) 塗膜の乾燥 塗装終了後塗板を温度 $20 \pm 1^{\circ} \mathrm{C}$, 湿 度 $73 \pm 5 \%$ の恒温恒湿室中に水平に 48 時間放置

\section{$4 \cdot 4$ 色差 $(\Delta E)$ による色判定方法の設定}

現在実際に支障なく使用されている塗料の色のバラッ キ調査の結果や塗料製造時の入手原料括よび顔料分散状 態などのバラッキを考慮すれば，国鉄で現在使用してい る外部用20色についての色差は, 定常状態にあるハンタ 一型色差計を用いて， $4 \cdot 3$ の条件で作成した試験片と色 標準 (承認板) を使用すれば $\Delta E$ は 2 以内に沶さえるこ とが可能である。またこの程度の色差值を設定すれば塗 料を使用する上で大きな支障は生じないと考えられる。

\section{5. あ と がき}

限られた分野でしか論じられなかった色彩に対する関 心が近時工業界方面にも大いに高まり, 色彩提供者であ る塗料メーカーに対する要求は，ますますきびしくなっ てきている色の良否判断は初めにも述べたように大部分 が視感で行なわれているが視感覚は識別能力は高いが周 囲の条件にまどわされやすい欠点があり，しばしば同一 物に対してらがった判定を下すことがある

例 : 同一塗料を塗ったものでも形の大小や, 塗ったも のが置かれている背景などの差により異なった色 感をもつ。

したがって芸術的感覚を楽しむものは別として工業的に 使用される場合の色判定は, 誰でもがいつでも同一物に 対してはあるバラッキ範团内で同じ判断が下せるような 合理的方法でなければならない。合理的客観的判定法と しては, 数值管理のできる計測器判定の方が適切であり 本稿では各種計測器の中からもっとも簡便で実用的な ンター型色差計による $\Delta E$ 判定を取り上げた次第であ る。な拉 $\Delta E$ 判定に際しては定常性の維持された色差計 を使用することが，測定上の重要ポイントである。しか 乙現在の色差計はその器機構造上から考它て精度維持に は細心の注意を払う必要がある。この点に関しては器機 を改良することにより，管理の手間を省さしかも目的精 度の維持も可能と考えられるので是非器機メーカー側で の改良検討を和願いしたい。

文献

1）車輛用塗料拈よび同試験方法の規格の研究報告 日本鉄道車輛工業協会

2）測色の理論と測定 :「染料と薬品」第 9 巻第 10 号 （1964）別刷

3) ASTM-D-1365-55 T 